\title{
The Effect of Occupational Noise Exposure on Blood and Biochemical Parameters: A Case Study of an Insulator Manufacturer in Iran
}

\begin{abstract}
Hamzeh Mohammadi ${ }^{1}$, Iraj Alimohammadi ${ }^{2}$, Saman Roshani ${ }^{3}$, Reza Pakzad ${ }^{4}$, Mohammad Bagher Abdollahi ${ }^{5}$, Somayeh Farhang Dehghan ${ }^{6}$
\end{abstract}

${ }^{1}$ M.Sc. Student, Department of Occupational Health, School of Public Health, Tehran University of Medical Sciences, Tehran, Iran

${ }^{2}$ Ph.D., Assistant Professor, Department of Occupational Health, School of Public Health, Iran University of Medical Sciences, Tehran, Iran

${ }^{3}$ B.Sc. Student, Department of Occupational Health, School of Public Health, Tehran University of Medical Sciences, Tehran, Iran

${ }^{4}$ Ph.D. Student, Department of Epidemiology and Biostatistics, School of Public Health, Tehran University of Medical Sciences, Tehran, Iran

${ }^{5}$ M.Sc., Department of Occupational Health, School of Public Health, Shahid Beheshti University of Medical Sciences, Tehran, Iran

${ }^{6}$ Ph.D. Candidate, Department of Occupational Health, School of Public Health, Tehran University of Medical Sciences, Tehran, Iran

\section{Type of article: Original}

\begin{abstract}
Introduction: Occupational noise is among the most critical occupational hazards, which, in addition to hearing loss, can cause other adverse consequences on an individual's physical and mental health. Long-term exposure to noise can affect blood and biochemical parameters and subsequently lead to increased risk of cardiovascular disease. This study investigated the effect of occupational exposure to noise on blood and biochemical parameters of workers in an insulator manufacturing plant.

Methods: This case-control study was conducted on workers in the production section (49 people as a case group) and the administrative staff (10 people as a control group) in one insulator manufacturing plant from 2010 to 2014. To assess individual exposure of workers to noise, the noise dosimeter model TES-1355 was used. Noise dosimetry testing was done based on the exposure pattern of workers to noise in compliance with the Iranian national standard (the criterion level of $85 \mathrm{dBA}$ and the exchange rate of $\mathrm{Q}=3 \mathrm{dBA}$ ). Blood parameters such as blood glucose, cholesterol, red blood cells (RBC), white blood cells (WBC), hemoglobin (Hb), and hematocrit (Hct) were studied in production workers (case) and administrative staff (control) over five consecutive years. The data were analyzed by software (SPSS-22) using the t-test, Mann-Whitney test, Fisher exact test, and Greenhouse-Geisser test.

Results: No significant difference was found among the demographic data of the two groups $(p>0.05)$. Average of glucose and cholesterol levels in the two groups was statistically significant $(p<0.05)$ and blood glucose levels in the case group significantly reduced over time and cholesterol increased $(p<0.001)$. Mean difference of RBC number, WBC number, and serum levels of $\mathrm{Hb}$ and Hct was statistically significant between the two groups $(\mathrm{p}<0.05)$. In addition, these hematological parameters increased among workers during these years.

Conclusion: Occupational exposure to noise may have a significant effect on an individual's blood parameters, which will cause harmful effects on worker health. Therefore, industrialists must take preventive measures in the field of noise control.
\end{abstract}

Keywords: dosimetry, occupational exposure, blood parameters, insulator

\section{Corresponding author:}

Somayeh Farhang Dehghan. Department of Occupational Health, School of Public Health, Tehran University of Medical Sciences, Tehran, Iran. Tel: +98.2188951390, Fax:+98.2188954781, E-mail: farhang@razi.tums.ac.ir Received: August 18, 2015, Accepted: October 17, 2015, Published: January 2016 iThenticate screening: October 28, 2015, English editing: November 05, 2015, Quality control: December 26, 2015 (C) 2015 The Authors. This is an open access article under the terms of the Creative Commons Attribution-NonCommercialNoDerivs License, which permits use and distribution in any medium, provided the original work is properly cited, the use is non-commercial and no modifications or adaptations are made. 


\section{Introduction}

A major risk in life is an occupational hazard, which typically arises as a result of exposure to specific harmful agents at the workplace (1). Workers in different industrial environments are constantly exposed to many environmental agents such as heat, vibration, cold, humidity, lighting, noise, etc., which are considered as the greatest threats to productivity and efficiency of workplaces and can affect the health, comfort, and performance of workers (2). In addition to various workplace hazards, noise pollution is a major health problem in many industries, which typically lack the required prevention and may lead to physiological, psychological, economic, and social complications among those who are exposed (3). At least 30 million people in America are exposed to noise that exceeds the limit value $(3,4)$. The proportion of population exposed to environmental noise above $65 \mathrm{dBA}$ has increased from $15 \%$ to $26 \%$ in the European Union over the past 10 years (5). According to reports in the European Union, $28 \%$ of workers in occupational environments are exposed to high-level noise (6). Statistics in developing countries, due to low control facilities, are much greater (7). It is also estimated that more than six million people in the world are exposed to noise above 85 decibels $(\mathrm{dB})$ in their work environment (8). Insulator manufacturing is one such industry that is at risk of noise pollution and its consequences. An insulator is a device that has a high electrical resistance and is used as good electrical insulation between two conductors with different voltage levels and between a conductor and earth as well. An insulator effectively prevents electrical discharge and is applicable in transmission and distribution of electrical energy. Many countries in the world such as the United States, China, Spain, Iran, Britain, France, South Africa, Russia, Australia, Germany, Canada, India, Japan, and Greece are producing this type of protective device and their employees are exposed to the noise pollution from milling, mixing, pressing, drying, assembling, cutting, grinding, extruding, and glazing equipment in its production process $(9,10)$.

Exposure to noise except hearing loss as the most characteristic effect causes other negative health consequences. Generally, the biological effects of noise are divided into two parts: auditory and nonauditory (13-11). Nonauditory effects of noise include physiological, interference with activities, and psychological. Noise at all levels causes body peripheral vasoconstriction (14-16). Heart rate can change as a result of noise; its cardiac output will be reduced and breathing will become rapid (17). Increased systolic and diastolic blood pressure upon exposure to noise higher than $85 \mathrm{dBA}$ has been observed in most human studies (18-20). Other studies have shown that exposure to noise can increase blood pressure and the risk of cardiovascular disease, which, in the long term, tends to increase with age and work experience (21-23). Other studies have shown the effect of noise pollution on blood and immune system cells (24). Sabahi, studying the effect of noise on blood parameters in mice, showed that exposure to noise increases the number of red blood cells, white blood cells, hemoglobin, and hematocrit of blood cells. He also demonstrated that noise pollution is accompanied with reducing the average volume of blood cells (MCV), the average size of hemoglobin $(\mathrm{MCH})$, and mean cell hemoglobin concentration (MCHC) (25). Other studies have shown that noise pollution can increase red blood cells, hematocrit, and hemoglobin (26). Noise effects are also said to have an impact on food and water consumption rates and also the pituitary hormones in the plasma $(28,27)$, which, in turn, alters biochemical parameters, including triglycerides, glucose, cholesterol, etc. Various studies have demonstrated an increase in the level of blood serum cholesterol and decrease in glucose levels in noise exposure (29-31). Studies on mice have shown that exposure to noise can increase blood cholesterol (32). Human studies also have shown the impact of workplace noise on increased cholesterol and triglyceride levels (33). Animal studies have shown that noise pollution reduces blood cholinesterase enzyme activity and the amount of glycogen stored in the liver (34). Other studies have confirmed elevated levels of cortisol as a result of noise exposure (35), which, in turn, increase total cholesterol, LDL (bad cholesterol or low-density lipoprotein), triglycerides, decreased cholesterol HDL (good cholesterol or high-density lipoprotein), and impaired insulin secretion (33). Thus far, no study has investigated the effect of noise pollution on hematological and biochemical parameters of industry workers over a period of several years. Given the growing importance of workforce health as the promoter of industry in the world, the aim of this study is to investigate the effect of occupational noise exposure on blood and biochemical parameters of insulator manufacturing plant workers.

\section{Material and Methods}

This case-control study was done among healthy male workers in the production section (49 people in the case group) and the administrative staff (10 people as the control group) in an insulator factory in Saveh, Iran, from 2010 to 2014. Referring to medical records of the subjects and consulting with the factory physician, workers with underlying diseases, such as cardiovascular and blood and using certain medications, were excluded from the study. Because its workers are typically exposed to noise levels higher than the recommended value, this particular factory was selected for this study. Referring to periodic environmental surveys from 2010 to 2014, noise exposure levels 
measured by individual dosimetry model TES - 1345 (Sunlight Electronic Technology Co. Ltd., China) in accordance with standard no. ISO9612 $(36,37)$ were recorded for each subject. Referring to participants' medical records, test results carried out for blood and biochemical parameters, including serum glucose (FBS), total cholesterol, the number of red blood cells (RBC) and white blood cells (WBC), hemoglobin (Hb), hematocrit (Hct), mean corpuscular blood volume (MCV), mean size of hemoglobin $(\mathrm{MCH})$, mean corpuscular hemoglobin concentration (MCHC) were recorded for each subject. All blood samples were analyzed in the Subspecialty Hospital Alzahra in Saveh. To analyze the data and determine the relationship among various parameters, the software package SPSS-22 was used. The t-test and Mann-Whitney test, Fisher exact test, and Greenhouse-Geisser test were applied to determine statistical significance.

\section{Results}

According to the results of the demographic data, the mean age of the subjects was 38.13 (6.2) years. This demographic parameter showed no statistically significant difference between the two groups (Table 1). Mean height and weight were $173.03(6.49) \mathrm{cm}$ and $78.83(11.44) \mathrm{kg}$, respectively. Also, there was no statistically significant difference among the parameters of weight, height, and smoking status between the groups (Table 1). The results of noise dosimetry in this study showed (Table 2) that participants engaging in both administrative and production sections are subject to different levels of noise. The Mann-Whitney test revealed a significant difference between the noise exposure level between two groups; as expected, noise levels in the production section are higher than in the administrative section $(\mathrm{p}<0.001)$. Biochemical analysis of blood parameters showed that blood glucose (FBS) in the production workers decreased during 2010-2014, while minor changes in FBS can be observed in the administrative staff during these years (Table 3).

Table1. Comparison of Demographic Characteristics between Exposed and Unexposed Group

\begin{tabular}{|c|c|c|c|c|}
\hline \multicolumn{2}{|c|}{ Variable } & Exposed & Unexposed & $\mathrm{p}$-value \\
\hline \multicolumn{2}{|c|}{ Age (year) } & $37.44(5.59)$ & $41.5(8.15)$ & $\mathrm{NS}^{\#}$ \\
\hline \multicolumn{2}{|c|}{ Height $(\mathrm{cm})$} & $173.34(6.34)$ & $171.5(7.36)$ & $\mathrm{NS}^{\#}$ \\
\hline \multicolumn{2}{|c|}{ Weight $(\mathrm{kg})$} & $77.18(10.02)$ & $81(17.17)$ & $\mathrm{NS}^{\#}$ \\
\hline \multirow[t]{2}{*}{ Smoke } & Yes & $8(80 \%)$ & $2(16.3 \%)$ & \multirow[t]{2}{*}{$\mathrm{NS}^{\ddagger}$} \\
\hline & No & $41(83.7 \%)$ & $8(16.3 \%\}$ & \\
\hline
\end{tabular}

$\mathrm{NS}=$ Not significant, \# based on t-test, $¥$ Based on Fisher exact test

Table 2. Comparison of Noise Exposure Level between Understudy Groups

\begin{tabular}{|l|l|l|l|l|l|}
\hline Variable & $\begin{array}{l}\text { Threshold Limit Value } \\
\text { (8-hr TWA) }(\mathrm{dBA})\end{array}$ & Year & Case & Control & p-value \\
\hline $\begin{array}{l}\text { Noise level (8-hr TWA) } \\
\text { (dBA) }\end{array}$ & 85 & 2010 & $83.9(5.40)$ & $66.6(0.25)$ & $<0.001$ \\
\cline { 2 - 6 } & & 2011 & $83.3(5.30)$ & $65.3(0.63)$ & $<0.001$ \\
\cline { 2 - 6 } & & 2012 & $83.7(4.98)$ & $67.4(0.3)$ & $<0.001$ \\
\cline { 2 - 6 } & & 2013 & $84.1(5.62)$ & $65.3(0.34)$ & $<0.001$ \\
\cline { 2 - 6 } & & 2014 & $82.6(3.3)$ & $65(0.93)$ & $<0.001$ \\
\hline
\end{tabular}

Table 3. Comparison of FBS and Cholesterol between Understudy Groups

\begin{tabular}{|c|c|c|c|c|c|}
\hline Variable & Normal Level & Year & Case & Control & p-value \\
\hline \multirow[t]{5}{*}{ FBS (mg/ml) } & \multirow[t]{5}{*}{$<100(\mathrm{mg} / \mathrm{ml})$} & 2010 & $90.04(6.54)$ & $94.70(3.86)$ & 0.034 \\
\hline & & 2011 & $88.48(7.71)$ & $95.60(5.12)$ & 0.007 \\
\hline & & 2012 & $87.08(10.41)$ & $95.50(5.56)$ & 0.016 \\
\hline & & 2013 & $87.38(8.38)$ & $93.10(6.00)$ & 0.046 \\
\hline & & 2014 & $86.22(12.08)$ & $95.20(7.36)$ & 0.028 \\
\hline \multirow{5}{*}{$\begin{array}{l}\text { Cholesterol } \\
(\mathrm{mg} / \mathrm{dl})\end{array}$} & \multirow[t]{5}{*}{$<200(\mathrm{mg} / \mathrm{dl})$} & 2010 & $162.63(25.39)$ & $191.60(35.79)$ & 0.003 \\
\hline & & 2011 & $165.2(26.49)$ & $193.2(36.88)$ & 0.006 \\
\hline & & 2012 & $169.95(29.25)$ & $191.5(27.16)$ & 0.036 \\
\hline & & 2013 & $173.02(27.32)$ & $192.3(20.84)$ & 0.040 \\
\hline & & 2014 & $175.44(27.89)$ & $194.8(12.35)$ & 0.002 \\
\hline
\end{tabular}


The Greenhouse-Geisser test results showed that blood glucose levels in the case group significantly decreased over time $(\mathrm{p}<0.001)$. The $\mathrm{t}$-test indicated significant difference between the average blood glucose levels over the study period $(p<0.05)$. Blood cholesterol levels measured in workers increased over the years, but there were not a lot of changes of it in the administrative staff. There was a significant difference between the mean cholesterol in both groups during the study years $(\mathrm{p}<0.05)$. Results of the study parameters of blood (the red blood cell $[\mathrm{RBC}]$ ) during the study years showed an increasing trend in the case group, while there were no significant changes in the control group (Table 4). A significant difference was found between the mean of RBC in two groups $(\mathrm{p}<0.05)$. During 2010-2014, the amount of white blood cells (WBC) in production workers grew, while small changes were seen in the control group. WBC mean was statistically significant between the two groups $(p<0.05)$. During five years of study, hemoglobin levels increased in the case group, while there were no significant changes in the control group, and the difference between the two groups was considered statistically significant $(\mathrm{p}<0.05)$.

Table 4. Comparison of RBC, WBC, HB, and HCT between Understudy Groups

\begin{tabular}{|c|c|c|c|c|c|}
\hline Variable & Normal Level & Year & Case & Control & p-value \\
\hline \multirow{5}{*}{$\begin{array}{l}\mathrm{RBC} \\
\text { (cells/ml) }\end{array}$} & \multirow[t]{5}{*}{$4.7-6.1$} & 2010 & $5.86(0.31)$ & $5.18(0.26)$ & $<0.001$ \\
\hline & & 2011 & $5.92(0.32)$ & $5.25(0.3)$ & $<0.001$ \\
\hline & & 2012 & $6.08(0.35)$ & $5.76(0.38)$ & 0.015 \\
\hline & & 2013 & $6.13(0.35)$ & $5.36(0.5)$ & $<0.001$ \\
\hline & & 2014 & $6.09(0.36)$ & $5.26(0.59)$ & 0.002 \\
\hline \multirow{5}{*}{$\begin{array}{l}\text { WBC } \\
\text { (cells/ml) }\end{array}$} & \multirow[t]{5}{*}{$4.5-10$} & 2010 & $6.54(0.87)$ & $5.9(0.89)$ & 0.041 \\
\hline & & 2011 & $6.77(0.73)$ & $6.16(0.51)$ & 0.015 \\
\hline & & 2012 & $6.97(1.45)$ & $5.93(0.79)$ & 0.034 \\
\hline & & 2013 & $7.14(1.00)$ & $6.3(1.18)$ & 0.023 \\
\hline & & 2014 & $7.46(1.73)$ & $6.18(1.43)$ & 0.033 \\
\hline \multirow{5}{*}{$\begin{array}{l}\text { Hemoglobin } \\
(\mathrm{g} / \mathrm{dl})\end{array}$} & \multirow[t]{5}{*}{$13.5-17.5$} & 2010 & $14.88(0.78)$ & $14.32(0.84)$ & 0.046 \\
\hline & & 2011 & $15.54(0.81)$ & $14.88(0.85)$ & 0.024 \\
\hline & & 2012 & $15.79(0.77)$ & $14.94(0.84)$ & 0.003 \\
\hline & & 2013 & $16.08(1.13)$ & $15.27(0.58)$ & 0.003 \\
\hline & & 2014 & $16.35(0.90$ & $14.88(0.88)$ & $<0.001$ \\
\hline \multirow{5}{*}{$\begin{array}{l}\text { Hematocrit } \\
(\%)\end{array}$} & \multirow[t]{5}{*}{$38.8-50$} & 2010 & $44.99(2.42)$ & $43.22(2.16)$ & 0.036 \\
\hline & & 2011 & $45.51(1.72)$ & $44.1(2.28)$ & 0.030 \\
\hline & & 2012 & $48.17(2.74)$ & $44.7(3.85)$ & 0.001 \\
\hline & & 2013 & $49.78(1.99)$ & $45.89(2.55)$ & $<0.001$ \\
\hline & & 2014 & $50.81(1.87)$ & 48.31 (3.04) & 0.030 \\
\hline
\end{tabular}

Table 5. Comparison of MCV, MCH, and MCHC between Understudy Groups

\begin{tabular}{|c|c|c|c|c|c|}
\hline Variable & Normal Level & Year & Case & Control & p-value \\
\hline \multirow{5}{*}{ MCV (fL) } & \multirow[t]{5}{*}{$80-100$} & 2010 & $88.53(4.95)$ & $83.02(3.49)$ & 0.001 \\
\hline & & 2011 & $87.79(4.59)$ & $83.88(3.62)$ & 0.014 \\
\hline & & 2012 & $86.11(2.93)$ & $83.16(3.49)$ & 0.038 \\
\hline & & 2013 & $86.11(2.93)$ & $83.16(3.49)$ & 0.007 \\
\hline & & 2014 & $84.79(3.42)$ & $82.26(3.57)$ & 0.038 \\
\hline \multirow{5}{*}{$\begin{array}{l}\mathrm{MCH} \\
\text { (pg/cell) }\end{array}$} & \multirow[t]{5}{*}{$27-31$} & 2010 & $32.56(1.97)$ & $29.97(1.60)$ & $<0.001$ \\
\hline & & 2011 & $32.00(2.00)$ & $29.3(5.17)$ & NS \\
\hline & & 2012 & $29.90(2.16)$ & $28.37(1.31)$ & 0.036 \\
\hline & & 2013 & $28.84(1.52)$ & $27.93(1.69)$ & 0.022 \\
\hline & & 2014 & $28.00(2.00)$ & $26.7(1.65)$ & 0.002 \\
\hline \multirow{5}{*}{$\begin{array}{l}\mathrm{MCHC} \\
(\mathrm{g} / \mathrm{dl})\end{array}$} & \multirow[t]{5}{*}{$32-36$} & 2010 & $35.48(1.68)$ & $33.72(1.18)$ & 0.003 \\
\hline & & 2011 & $34.00(0.00)$ & $33.1(1.38)$ & 0.000 \\
\hline & & 2012 & $33.42(1.16)$ & $33.43(1.52)$ & NS \\
\hline & & 2013 & $32.47(1.89)$ & $37.26(1.07)$ & 0.006 \\
\hline & & 2014 & $31.77(1.89)$ & $33.55(1.07)$ & 0.006 \\
\hline
\end{tabular}

Hematocrit levels were increased in the case group, while there were not many changes in hematocrit levels among the workers. The difference between the two groups in terms of hematocrit mean was statistically significant (p $<$ 
0.05). Comparing the blood cells' volume mean (MCV) with that of the control group (Table 5) showed that, during 2010-2014, MCV reduced in the exposed group, while many changes were not observed in the case group; this difference between the two groups was statistically significant $(p<0.05)$. Also, the average size of hemoglobin $(\mathrm{MCH})$ in the case group was reduced during the study, but a significant trend was not observed in the control group. $\mathrm{MCH}$ mean difference between the two groups was statistically significant in all years of study ( $\mathrm{p}<0.05)$. There was a similar result for mean cell hemoglobin concentration (MCHC).

\section{Discussion}

This study aimed to investigate the effect of occupational noise exposure on blood parameters among workers of an insulator manufacturing plant. Several studies were done on physiological and psychological parameters in regards to the effects of noise exposure. In these studies, noise effects on increasing cardiovascular problems and risk of heart attack has been shown (14-16). Increased blood cholesterol due to noise exposure in laboratory mice was observed in the study of Prabhakaran and colleagues, in which they knew the effect due to changes in pituitary hormones (32). The study of Samuel and colleagues also indicated an increase in cholesterol and triglyceride levels due to increase of workplace noise in subjects (33). The results of this study also demonstrated a statistically significant difference in average blood cholesterol levels between production workers who were statistically exposed to higher noise than the administrative staff. The five-year changes in the case group had more obvious increased trends than in the administrative group. Several studies have been conducted on noise effects increasing blood cortisol levels, which demonstrated that increased cortisol level increases blood cholesterol in people who are exposed to noise $(29,35)$. Several studies demonstrated changes in pituitary hormone secretion as a result of exposure to noise, which can change cholesterol, triglycerides, and blood glucose levels as a result of noise exposure. The various studies show that serum cholesterol level increases and blood glucose level decreases in increased noise exposure. The health effects of noise (such as increased cholesterol, blood glucose, etc.) may happen as a direct result of exposure to noise or may be a reaction of the body, such as discomfort and dissatisfaction caused by noise exposure (31-29), and the results of the present study indicate the issue. In this study, the cholesterol variable in the case group was more than that of the control group; this difference was statistically significant in all years of study $(\mathrm{p}<0.05)$. Cholesterol had an increasing trend in the case group, which corresponds with field studies. The FBS variable in the control group was higher than in the case group, and there was a significant difference between them, which is in line with studies in this area, although the FBS had a decreasing trend in the production group during the study years.

A study conducted by Sabahi and colleagues demonstrated that the number of red blood cells, white blood cells, hemoglobin, and hematocrit of blood cells of mice increases due to noise exposure, which is due to the effect of vibrating sound on the immune system and increasing blood parameters (25). A study conducted by Boiko concluded that noise pollution can increase red blood cell count, hematocrit, and hemoglobin in oil refinery workers, while the mechanism of this process remained unclear (26). In this study, the RBC was significantly different between production and administrative groups $(\mathrm{p}<0.05)$, and an increasing trend was seen in the workers. WBC, in addition to that of the case group in all the years of study, was significantly different between the two groups ( $\mathrm{p}<$ 0.05). The values of hemoglobin and hematocrit variables were increased during the study years of the case group, and the difference between the two examined groups was significant in all years of study $(p<0.05)$. The results of this study are in accordance with past studies. The other results of a study conducted in 2002 by Sabahi and colleagues on the effects of noise on blood cells and parameters of mice showed that exposure to noise reduces mean cell volume $(\mathrm{MCV})$, mean cell hemoglobin $(\mathrm{MCH})$, and mean cell hemoglobin concentration (MCHC) in blood (25). In the present study, the variables $\mathrm{MCV}, \mathrm{MCH}$, and $\mathrm{MCHC}$ have been decreased; there was also a significant difference between the two groups.

\section{Conclusions}

In summary, the findings showed that the parameters of $\mathrm{MCV}, \mathrm{MCH}, \mathrm{FBS}$, and $\mathrm{MCHC}$ were decreased during the study years among production workers exposed to noise, and parameters of cholesterol, RBC, WBC, Hb, and Hct were increased more than that of the administrative workers. Thus, it is clear that there are significant changes on blood parameters of these workers, which can have adverse effects on their health in the future. Because exposure to noise can increase stress, tissue dysfunction, and cause changes in the normal process of secretion of the body's hormones, thus resulting in significant effects on blood parameters and health, it is recommended that industrialists perform preventive measures on administrative/engineering controls of noise. However, a definitive conclusion on 
the effects of exposure to high levels of occupational noise on blood parameters is subject to more extensive laboratory and field studies, which can simultaneously study the more influential factors on blood parameters.

\section{Acknowledgments:}

The authors gratefully acknowledge all those who participated in this work.

\section{Conflict of Interest:}

There is no conflict of interest to be declared.

\section{Authors' contributions:}

All authors contributed to this project and article equally. All authors read and approved the final manuscript.

\section{References}

1) Nassiri P, Monazzam MR, Asghari M, Zakerian SA, Dehghan SF, Folladi B, et al. The interactive effect of industrial noise type, level and frequency characteristics on occupational skills. Perform Enhanc Health. 2015. doi: 10.1016/j.peh.2015.01.001

2) Naravane S. Effect of industrial noise on occupational skill performance capability. Unpublished Master of Science's thesis. Binghamton, USA: State University of New York, 2009.

3) Tak S, Davies RR, Calvert GM. Exposure to hazardous workplace noise and use of hearing protection devices among US workers-NHANES, 1999-2004. Am J Ind Med. 2009; 52(5): 358-71. doi: 10.1002/ajim.20690, PMID: 19267354.

4) Seixas NS, Goldman B, Sheppard L, Neitzel R, Norton S, Kujawa SG. Prospective noise induced changes to hearing among construction industry apprentices. Occup Environ Med. 2005;62(5): 309-17. PMID: 15837852.

5) Clerici WJ, DiMartino DL, Prasad MR. Direct effects of reactive oxygen species on cochlear outer hair cell shape in vitro. Hear Res. 1995; 84(1-2): 30-40. PMID: 7642453.

6) European Agency for Safety and Health at Work (EASHW). Monitoring the state of occupational safety and health in the European Union-pilot study. Luxembourg, EASHW, 2000. Avilable from: https://osha.europa.eu/en/tools-and- publications/publications/reports/401.

7) Morata TC, Fiorini AC, Fischer FM, Colacioppo S, Wallingford KM, Krieg EF, et al. Toluene-induced hearing loss among rotogravure printing workers. Scand J Work Environ Health. 1997; 23(4): 289-98, doi: 10.5271/sjweh.222, PMID: 9322820.

8) Kopke RD, Weisskopf PA, Boon JL, Jackson RL, Wester DC, Hoffer ME, et al. Reduction of noiseinduced hearing loss using L-NAC and salicylate in the chinchilla. Hear Res. 2000; 149(1-2): 138-46, doi: 10.1016/S0378-5955(00)00176-3, PMID: 11033253.

9) Linsley T. Basic electrical installation work, 6th ed. Waltham: Elsevier, 2011.

10) Gish NE. Collector's Guide for Porcelain Insulators. Lumberton: Elton Gish, 2015.

11) Nassiri P, Dehghan SF, Monazzam MR. A prioritization approach for noise risk management in a petrochemical complex. J Occup Health. 2013; 55(3): 204-10. PMID: 23485573

12) Basner M, Babisch W, Davis A, Brink M, Clark C, Janssen S, Stansfeld S. Auditory and non-auditory effects of noise on health. Lancet. 2014;383(9925):1325-32. doi: 10.1016/S0140-6736(13)61613-X. PMID: 24183105.

13) Zamanian Z, Monazzam MR, Satyarvand M, Dehghan SF. Presentation of a Model to Identify Dominant Noise Source in Agricultural Sector of Sugarcane Industry. Adv Environ Biol. 2012. 6 (11), 3002-6.

14) P Nassiri, MR Monazzam, SF Dehghan, M Jahangiri. The assessment of the environmental and personal noise in a petrochemical plant. Iran Occupational Health. 2013. 10 (1), 23-32.

15) Agrawal Y, Niparko JK, Dobie RA. Estimating the effect of occupational noise exposure on hearing thresholds: the importance of adjusting for confounding variables. Ear Hear. 2010; 31(2): 234-7. doi: 10.1097/AUD.0b013e3181c6b9fd, PMID: 20075736.

16) Ising H, Kruppa B. Health effects caused by noise: evidence in the literature from the past 25 years. Noise Health. 2004; 6(22): 5-13. PMID: 15070524.

17) Chepesiuk R. Decibel hell: the effects of living in a noisy world. Environ Health Perspect. 2005; 113(1): A34-41. PMID: 15631958, PMCID: PMC1253729.

18) Lang T, Fouriaud C, Jacquinet-Salord MC. Length of occupational noise exposure and blood pressure. Int Arch Occup Environ Health. 1992; 63(6): 369-72, doi: 10.1007/BF00386929, PMID: 1544682 
19) Huang J, Deng F, Wu S, Lu H, Hao Y, Guo X. The impacts of short-term exposure to noise and trafficrelated air pollution on heart rate variability in young healthy adults. J Expo Sci Environ Epidemiol. 2013; 23(5): 559-64. doi: 10.1038/jes.2013.21, PMID: 23591697

20) Kraus U, Schneider A, Breitner S, Hampel R, Rückerl R, Pitz M, et al. Individual daytime noise exposure during routine activities and heart rate variability in adults: a repeated measures study. Environ Health Perspect. 2013 May; 121(5): 607-12. doi: 10.1289/ehp.1205606, PMID: 23512292.

21) Tomei F, Fantini S, Tomao E, Baccolo TP, Rosati MV. Hypertension and chronic exposure to noise. Arch Environ Health. 2000; 55(5): 319-25, doi: 10.1080/00039890009604023, PMID: 11063406.

22) Tomei F, Papaleo B, Baccolo TP, Tomao E, Alfi P, Fantini S. Chronic noise exposure and the cardiovascular system in aircraft pilots. Med Lav. 1996; 87(5): 394-410. PMID: 9045028.

23) Abbate C, Giorgianni C, Munao F, Costa C, Brecciaroli R, Barbaro M. Effects of noise on functional cardiovascular parameters: a followup study. G Ital Med Lav Ergon. 2002; 24(1): 43-8. PMID: 11892416.

24) Sobrian SK, Vaughn VT, Ashe WK, Markovic B, Djuric V, Jankovic BD. Gestational exposure to loud noise alters the development and postnatal responsiveness of humoral and cellular components of the immune system in offspring. Environ Res. 1997; 73: 227- 41. PMID: 9311552.

25) Sabahi A, Moradi I. The Effects of Noise Exposure on Rat's Hematologic Parameters and Red Cell Indices. IJMS. 2002; 27(2)

26) Borko V. Hygienic characteristics of working conditions and health status of workers engaged in the production of benzene and xylenes at a petroleum refinery. Gigiena truda i professional'nye zabolevaniia. 1970; 14(6): 23-5. PMID: 5433672.

27) Armario A, Castellanos JM, Balasch J. Effects of chronic noise on corticotrophin function and emotional reactivity in adult rats. Neuroendocrinology. 1984; 6(2): 121-7.

28) Armario A, Castellanos JM , Balasch J. Chronic noise and water restriction as stress models in relation to food and water intake and hormonal profiles in adult male rats. Nutr Rep Int, 1983; 28(6): 1333-9.

29) Jóźkiewicz S, Puchalik M, Cygan Z, Drózdz M, Gregorczyk J, Grzesik J, et al. Studies on the effect of acoustic and ultra-acoustic fields on biochemical processes. IX. Effect on some blood components in men working under noisy conditions. Acta Physiol Pol. 1965;16:620.

30) Pawlicka E, Kalicinski A, Kordecki R, Nowak W, Proniewska W, Simonowicz K. Effect of noise on the level of free fatty acids in the blood. Acta physiologica Polonica. 1972; 23(6): 1021, PMID: 5864666.

31) Simpson GC, Cox T, Rothschild D. The effects of noise stress on blood glucose level and skilled performance. Ergonomics. 1974; 17(4): 481-7, doi: 10.1080/00140137408931378, PMID: 4442386.

32) Prabhakaran K, Suthanthirarajan N, Namasivayam A. Biochemical changes in acute noise stress in rats. Indian J Physiol Pharmacol. 1988; 32(2): 100-4, PMID: 3182056.

33) Melamed S, Froom P, Kristal-Boneh E, Gofer D, Ribak J. Industrial noise exposure, noise annoyance, and serum lipid levels in blue-collar workers-the CORDIS Study. Arch Environ Health. 1997; 52(4): 292-8. PMID: 9210730.

34) Tsapkov M, Kalistratova V, Tishchenko G. Combined effect of tritium oxide, noise and heat on rats. Radiobiologiia. 1981; 22(2): 275-7. PMID: 7089218.

35) Brandenberger G, Follenius M, Wittersheim G, Salame P, Siméoni M, Reinhardt B. Plasma catecholamines and pituitary adrenal hormones related to mental task demand under quiet and noise conditions. Biol Psychol. 1980; 10(4): 239-52. PMID: 6264980.

36) Chrousos GP. Stress and disorders of the stress system. Nat Rev Endocrinol. 2009; 5: 374-81. doi: 10.1038/nrendo.2009.106, PMID: 19488073.

37) Dehghan SF, Nassiri P, Monazzam MR, Aghae HA, Moradirad R, Haghighi Kafash Z, et al. Study on the Noise Assessment and Control at a Petrochemical Company. NVWW. 2013; 44(1): 10-18. doi: 10.1260/0957-4565.44.1.10 